$$
\text { удк } 330.341 .2
$$

JEL classification: C00, L97, L98, L99, R10, R23

\section{Олексій ТОпчІй}

кандидат економічних наук, докторант,

ДУ «/нститут економіки

природокористування та сталого розвитку НАН України», Україна

ORCID: https://orcid.org/ 0000-0001-6414-0561

(C) Олексій Топчій, 2020

Отримано: 11.01.2020 р.

Прорецензовано: 02.02.2020 p.

Рекомендовано до друку: 26.02.2020 р.

Опубліковано: 28.02.2020 p.

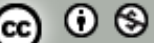

Ця стаття розповсюджується на умовах ліцензії Creative Commons AttributionNonCommercial 4.0, яка дозволяє необмежене повторне використання, розповсюдження та відтворення на будь-якому носії, за умови правильного цитування оригінальної роботи.
Олексій Топчій (Україна)

\section{ВПРОВАДЖЕННЯ ІННОВАЦІЙНИХ ТЕХНОЛОГІЙ У РОЗВИТОК ЖИТЛОВО-КОМУНАЛЬНОГО ГОСПОДАРСТВА: РЕГІОНАЛЬНИЙ АСПЕКТ}

\section{АНОТАЦІЯ}

Вступ. Впровадження інноваційних технологій розвитку ЖКг спрямовано насамперед на оптимізацію асортименту послуг у відповідності до потреб населення та раціоналізацію їх використання у контексті сталого розвитку територій.

Метою статті $€$ удосконалення використання інноваційних технологій для модернізації та розвитку житлово-комунального господарства на регіональному рівні.

Методи (методологія). У досліджені застосовані загальнонаукові методи, зокрема теоретичного узагальнення - для узагальнення особливостей та основних напрямів впровадження інноваційних технологій у розрізі основних функціональних сфер житлово-комунального господарства; системного економічного аналізу - для розрахунків показників технічного стану та ефективності роботи систем централізованого водопостачання у регіонах України

Результати. Досліджено особливості та основні напрямки впровадження інноваційних технологій у розрізі основних функціональних сфер житловокомунального господарства, а саме: технології модернізації житлового фонду у контексті забезпечення енергозбереження; напрями модернізації та підвищення енергоефективності систем теплопо- та енергопостачання, ресурсозберігаючі та екологічно безпечні системи водопостачання, водовідведення та очищення стічних вод; впровадження альтернативних джерел енергії для зміцнення енергетичної безпеки міських агломерацій; оптимізації систем транспортного забезпечення міст в напрямку розширення сфер використання міського транспорту та підвищення його екологічності, розвитку інформаційних технологій управління транспортними потоками, стимулювання переходу на екологічно безпечні види транспорту. Систематизовано проблеми та перспективні можливості впровадження інноваційних технологій в житлово-комунальній сфері із врахуванням зарубіжного досвіду.

Топчій О. Впровадження інноваційних технологій у розвиток житловокомунального господарства: регіональний аспект. Економічний аналіз. 2020. Том 30. № 1. Частина 2. С. 166-172.

DOI: https://doi.org/10.35774/econa2020.01.02.166

Ключові слова: інноваційні технології; модернізація; житлово-комунальне господарство; регіональні аспект. 
UDC 330.341 .2

JEL classification: C00, L97, L98, L99, R10, R23

\section{Oleksiy TOPCHIY}

$\mathrm{PhD}$ in Economics,

Doctoral Student,

Institute of Economics of Nature Management and Sustainable Development of the National Academy of Sciences of Ukraine, Ukraine ORCID: https://orcid.org/ 0000-0001-6414-0561

C Oleksiy Topchiy, 2020

Received: 11.01.2020

Revised: 02.02.2020

Accepted: 26.02.2020

Online publication date: 28.02 .2020

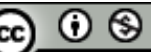

This is an Open Access article, distributed unde the terms of the Creative Commons AttributionNonCommercial 4.0 license, which permits unrestricted re-use, distribution, and reproduction in any medium, provided the original work is properly cited.
Oleksiy Topchiy (Ukraine)

\section{IMPLEMENTATION OF INNOVATIVE TECHNOLOGIES IN THE DEVELOPMENT OF HOUSING AND COMMUNAL ECONOMY: REGIONAL ASPECT}

\begin{abstract}
Introduction. The introduction of innovative technologies for housing development is aimed primarily at optimizing the range of services in accordance with the needs of the population and streamlining their use in the context of sustainable development.

The aim of the article is to improve the use of innovative technologies for modernization and development of housing and communal services at the regional level.

Methods (methodology). The general scientific methods, in particular theoretical generalization - for generalization of features and the basic directions of introduction of innovative technologies in a cut of the basic functional spheres of housing and communal services are investigated; system economic analysis - for calculations of indicators of technical condition and efficiency of centralized water supply systems in the regions of Ukraine.

Results. Peculiarities and main directions of introduction of innovative technologies in the context of the main functional spheres of housing and communal services, namely: technologies of modernization of housing stock in the context of providing energy saving are investigated; directions of modernization and increase of energy efficiency of heat and power supply systems, resource-saving and ecologically safe systems of water supply, drainage and sewage treatment; introduction of alternative energy sources to strengthen the energy security of urban agglomerations; optimization of urban transport systems in the direction of expanding the scope of urban transport and improving its environmental friendliness, development of information technologies for traffic management, stimulating the transition to environmentally friendly modes of transport. Problems and perspective possibilities of introduction of innovative technologies in the housing and communal sphere are systematized taking into account foreign experience.
\end{abstract}

Topchiy, O. (2020). Implementation of innovative technologies in the development of housing and communal economy: regional aspect. Economic analysis, 30 (1, Part 2), 166-172.

DOI: https://doi.org/10.35774/ econa2020.01.02.166

Keywords: innovative technologies; modernization; housing and communal services; regional aspect. 
www.econa.org.ua

\section{Вступ}

На сьогодні в галузі ЖКГ України функціонує кілька тисяч підприємств та організацій різних форм власності, які надають населенню понад 40 видів послуг на суму більше 6 млрд грн щороку. Тут використовується майже чверть основних фондів держави, зайнято $5 \%$ працездатного населення країни. Централізованим водопостачанням забезпечено населення всіх міст країни та $86 \%$ селищ міського типу (тобто понад 70 \% населення України), централізованими системами каналізації - 95 \% міст і більше половини селищ міського типу. Близько 80 \% теплової енергії, що виробляється підприємствами комунальної енергетики (а це 72 млн Гкал), відпускається населенню та об'єктам бюджетної сфери [1].

Впровадження інноваційних технологій розвитку ЖКГ спрямовано насамперед на оптимізацію асортименту послуг у відповідності до потреб населення та раціоналізацію їх використання у контексті сталого розвитку територій.

Дослідженню використання інноваційних технологій в модернізації житлово-комунального господарства міських агломерацій присвячені праці вчених науковців, зокрема: $Є$. Градобоєвою, А. Бабак, С. Бочаровим, I. Іртищевою, І. Крамаренко, М. Мельниковою, А. Омельченко, М. Стегней, Т. Стройко. Однак постійні процеси трансформації вимагають пошуку нових шляхів удосконалення регіонального забезпечення інноваційними технологія для розвитку та модернізації житлово-комунального господарства міських агломерацій.

\section{Мета статті}

Метою статті $€$ удосконалення використання інноваційних технологій для модернізації та розвитку житлово-комунального господарства на регіональному рівні.

\section{Виклад основного матеріалу}

Важливою сферою ЖКГ є управління житловим фондом, значна частина якого потребує заміни або суттєвої реконструкції із застосування енергозберігаючих технологій, матеріалів та обладнання. Основними завданнями модернізації житлового фонду $\epsilon$ впровадження енергоефективних технологій а також підключення будинкових комплексів та окремих будинків до альтернативних джерел енергії. В той час, як питання переведення багатоквартирних будинків на використання альтернативних джерел (сонячні батареї, вітрові установки тощо) гальмується проблемами організаційного, правового та фінансового характеру, процес утеплення будівель, встановлення будинкових лічильників обліку енергії та заміни застарілих систем енергопостачання певним чином просувається завдяки насамперед імплементації законів «Про житлово-комунальні послуги», «Про комерційний облік теплової енергії і водопостачання», «Про Фонд енергоефективності» тощо.

За даними порталу "Україна комунальна» [2], станом на липень 2019 року у середньому по Україні у 81,3 \% житлових та нежитлових будівель встановлені лічильники тепла, що свідчить про формування свідомого власника та споживача послуг та дозволяє споживачам оплачувати лише ту енергію і тепло, які спожиті реально. Серед лідерів за кількістю оснащених лічильниками тепла житлових будівель Черкаська (98 \%), Миколаївська (94,9 \%), Хмельницька (93,5 \%) та Вінницька області (93\%). Найнижчі показники у: Тернопільської $(15,5 \%)$, Луганської $(37,1 \%)$, Кіровоградської $(45,2 \%)$ областей.

На сьогодні модернізація житлового фонду, зокрема у міських агломераціях, стимулюється процесами формування об'єднань співвласників багатоквартирних будинків, що набувають статусу юридичної особи та мають право отримувати кредитні ресурси для проведення ремонтних робіт і встановлення енергоефективного обладнання, заключати договори з компаніями, що надають житлово-комунальні послуги та визначати тарифи на обслуговування будинків і прибудинкових територій.

Ефективна реалізація проектів щодо модернізації теплових та енергетичних мереж потребує насамперед чіткого визначення прав, обов'язків та відповідальності сторін як за процеси фінансування, так і за якість та терміни реалізації проектів. Проблемою дієвості реалізації проектів щодо впровадження нових технологій в умовах реформування системи ЖКГ та паралельних процесів децентралізації влади залишається пошук управлінського балансу у сфері фінансування, контролю та відповідальності. Вирішення проблем щодо розподілу повноважень та встановлення чітких, прозорих, зрозумілих громадськості процедур контролю за станом здійснення проектів у сфері ЖКг а також відповідної публічної звітності підрядників на кожному етапі реалізації дозволить підвищити дисципліну їх реалізації та впровадження.

Однією центральних проблем у сфері ЖКГ більшості регіонів $€$ безперебійне забезпечення населення питною водою належної якості. Сучасний стан систем водопостачання, водовідведення, очисних споруд та інших об'єктів інфраструктури водного господарства не відповідає вимогам часу через високий рівень зношеності обладнання, його аварійності, не відповідності технічного стану умовам експлуатації, обсягам 
www.econa.org.ua

попиту та природному потенціалу територій щодо забору води.

За даними Міністерства розвитку громад i територій [4] станом на кінець 2018 року послугами централізованого водопостачання на $100 \%$ було забезпечено населення міст лише у 3 областях (Київська, Одеська, Херсонська) та м. Київ. В окремих областях, серед яких Рівненська, Чернівецька, Івано-Франківська послугами централізованого водопостачання забезпечено менше 85 \% мешканців. Що стосується селищ міського типу середній рівень забезпечення центральним водопостачанням складає 42,3 \%, а в селах - від 79\% в Одеській області до 1,6\% у Тернопільській.

у більшості регіонів, окрім Волинської, Рівненської, Харківської та м. Київ не створено умови для цілодобового водопостачання населення. В окремих областях (Черкаська, Закарпатська, Дніпропетровська та Сумська) рівень цілодобового постачання води для населення не перевищує 30 \%. Проведений експертами Українського центру водно-екологічних проблем технічного стану аналіз стану систем централізованого водопостачання та водовідведення, дозволив систематизувати основні проблеми в галузі, вирішення яких потребує ії комплексної модернізації із врахуванням сучасних досягнень науки і техніки.

Перераховані

проблеми

системи водопостачання $€$ характерними майже для всіх населених пунктів. Проте, $\epsilon$ певні відмінності у системах водопостачання та водовідведення як у розрізі регіонів, так і населених пунктів, що повинні враховуватися у процесі проектування модернізації ЖКГ міських агломерацій (таблиця 1).

Таблиця 1. Показники технічного стану та ефективності роботи систем централізованого водопостачання у регіонах України за 2017-2018 роки*

\begin{tabular}{|c|c|c|c|c|c|c|c|c|c|}
\hline \multirow{2}{*}{ Регіони України } & \multicolumn{3}{|c|}{$\begin{array}{c}\text { Непродуктивні втрати } \\
\text { води у системах } \\
\text { водопостачання, \% до } \\
\text { піднятої }\end{array}$} & \multicolumn{3}{|c|}{$\begin{array}{c}\text { Витрати електроенергії у } \\
\text { системах водопостачання, } \\
\text { млн кВт год/рік }\end{array}$} & \multicolumn{3}{|c|}{$\begin{array}{c}\text { Частка аварійних та } \\
\text { ветхих водопровідних } \\
\text { мереж,\% }\end{array}$} \\
\hline & $\stackrel{\dot{2}}{\stackrel{-}{\circ}}$ & $\begin{array}{l}\dot{\infty} \\
\stackrel{\infty}{-1} \\
\stackrel{N}{N}\end{array}$ & $\frac{.0}{\frac{5}{a}}$ & $\stackrel{\dot{2}}{\stackrel{2}{O}}$ & $\begin{array}{l}\dot{\infty} \\
\stackrel{\infty}{-1} \\
\stackrel{N}{N}\end{array}$ & 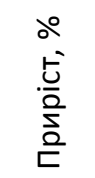 & $\stackrel{\dot{2}}{\stackrel{2}{O}}$ & $\begin{array}{l}\dot{\infty} \\
\stackrel{\infty}{-1} \\
\stackrel{N}{N}\end{array}$ & $\begin{array}{l}\text { ১゚ } \\
\frac{5}{0} \\
\frac{0}{5} \\
\frac{a}{E}\end{array}$ \\
\hline Вінницька & 36,7 & 37,2 & 0,5 & 40,2 & 41,1 & 2,2 & 34,9 & 29,8 & $-5,1$ \\
\hline Волинська & 29,7 & 28,6 & $-1,1$ & 16,2 & 15,9 & $-2,2$ & 48,7 & 46,5 & $-2,2$ \\
\hline Дніпропетровська & 31,9 & 30,7 & $-1,2$ & 255,3 & 250,7 & $-1,8$ & 38,7 & 37,4 & $-1,3$ \\
\hline Донецька & 39,2 & 41,2 & 2,0 & 678,0 & 681,4 & 0,5 & 56,1 & 54,6 & $-1,5$ \\
\hline Житомирська & 49,2 & 50,1 & 0,9 & 28,2 & 27,0 & $-4,3$ & 30,8 & 30,0 & $-0,8$ \\
\hline Закарпатська* & 50,6 & 48,4 & $-2,2$ & 25,3 & 24,5 & $-3,2$ & 15,2 & 12,3 & $-2,9$ \\
\hline Запорізька & 40,1 & 36,2 & $-3,9$ & 86,9 & 86,2 & $-0,8$ & 35,0 & 33,1 & $-1,9$ \\
\hline Івано-Франківська & 47,6 & 46,2 & $-1,4$ & 16,2 & 16,6 & 2,3 & 29,1 & 24,7 & $-4,4$ \\
\hline Київська & 38,4 & 28,0 & $-10,4$ & 69,8 & 67,8 & $-2,8$ & 16,5 & 14,2 & $-2,3$ \\
\hline Кіровоградська & 37,9 & 38,5 & 0,6 & 43,6 & 42,2 & $-3,3$ & 49,4 & 47,6 & $-1,8$ \\
\hline Луганська & 46,1 & 30,9 & $-15,2$ & 80,3 & 82,3 & 2,5 & 63,9 & 58,9 & $-5,0$ \\
\hline Львівська & 41,2 & 43,3 & 2,1 & 132,1 & 133,8 & 1,3 & 51,6 & 49,7 & $-1,9$ \\
\hline Миколаївська & 33,3 & 40,7 & 7,4 & 38,5 & 37,1 & $-3,6$ & 25,9 & 20,2 & $-5,7$ \\
\hline Одеська & 38,7 & 30,7 & $-8,0$ & 163,2 & 166,6 & 2,1 & 38,5 & 37,5 & $-1,0$ \\
\hline Полтавська & 20,4 & 39,0 & 18,6 & 52,3 & 51,2 & $-2,1$ & 29,9 & 29,0 & $-0,9$ \\
\hline Рівненська & 27,7 & 25,5 & $-2,2$ & 37,8 & 36,4 & $-3,8$ & 23,8 & 18,7 & $-5,1$ \\
\hline Сумська & 28,6 & 29,8 & 1,2 & 22,1 & 29,4 & 33,0 & 26,9 & 18,7 & $-8,2$ \\
\hline Тернопільська & 49,3 & 27,9 & $-21,4$ & 18,3 & 16,5 & $-9,8$ & 37,3 & 34,4 & $-2,9$ \\
\hline Харківська & 29,2 & 48,3 & 19,1 & 268,0 & 266,2 & $-0,7$ & 48,3 & 46,1 & $-2,2$ \\
\hline Херсонська & 27,2 & 30,6 & 3,4 & 245,0 & 250,7 & 2,3 & 38,8 & 36,3 & $-2,5$ \\
\hline Хмельницька & 29,1 & 28,3 & $-0,8$ & 39,2 & 38,5 & $-1,8$ & 39,2 & 35,8 & $-3,4$ \\
\hline Черкаська & 27,2 & 29,6 & 2,4 & 22,1 & 23,8 & 7,5 & 33,9 & 29,5 & $-4,4$ \\
\hline Чернівецька & 60,6 & 56,7 & $-3,9$ & 32,3 & 32,7 & 1,4 & 45,2 & 27,6 & $-17,6$ \\
\hline Чернігівська & 19,5 & 19,1 & $-0,4$ & 16,3 & 17,4 & 6,7 & 35,0 & 34,0 & $-1,0$ \\
\hline м. Київ & 27,3 & 29,1 & 1,8 & 152,3 & 156,4 & 2,7 & 44,9 & 44,5 & $-0,4$ \\
\hline
\end{tabular}

*Джерело: систематизовано автором за даними [3]. 
www.econa.org.ua

У 2018 році середній рівень непродуктивних витрат води по регіонам України становив 35,8\%, що на 0,5\% нижче, ніж у попередньому 2017 році. Найбільші обсяги втрат води в системах водопостачання (понад $50 \%$ ) спостерігалися у Чернівецькій (56,7\%) і Житомирській областях (50,1\%). Вище $40 \%$ вони становили у Харківській $(48,3 \%)$, Закарпатській $(48,4 \%)$, Івано-Франківській (46,2 \%), Львівській (43,3\%), Донецькій (41,2 \%) та Миколаївській областях (40,7%). Найменші втрати води у відсотках до піднятої були у Чернігівській області $(19,1 \%)$ та Рівненській $(25,5)$ областях.

Аналізуючи зміни щодо непродуктивних витрат у 2018 році порівняно з 2017 слід відмітити, що в окремих областях протягом року обсяги непродуктивних втрат води скоротилися більш, ніж на $10 \%$, зокрема за рахунок встановлення будинкових та по квартирних лічильників а також заміни частини обладнання насосних станцій. До таких областей відноситься Тернопільська (-21,4 \%), Луганська $(-15,2 \%)$ та Київська область $(-10,4 \%)$. Зростання обсягів непродуктивних витрат води спостерігається в Полтавській (18,6\%), Харківській $(19,1 \%)$ та Миколаївській області (7,4%).

Статистичні дані свідчать, що спостерігаються значні диспропорції серед регіонів щодо витрат електроенергії в системах водопостачання. У 2018 році в цілому по Україні в системах централізованого водопостачання було витрачено 2377,9 млн кВт/год електроенергії, що в середньому на 0,5\% більше, ніж у попередньому році. Різниця між максимальною та мінімальною енергоємністю систем водопостачання в регіонах складає понад 665,6 млн кВт/год. Найбільше витрат електроенергії на забезпечення В Донецькій $(681,4)$, Харківській $(266,2)$, Дніпропетровській $(250,69)$, Одеській $(166,6)$, Львівській $(133,81)$ областях та у м. Київ $(156,4)$ млн кВт/год. Відносно низькі витрати енергій в системах водопостачання спостерігаються переважно в Західних областях, зокрема у Волинській $(15,85)$, Тернопільській $(16,5)$, Івано-Франківській $(16,58)$.

Високі витрати енергї̈ в системах водопостачання характерні для великих промислових районів 3 великою чисельністю населення та розміщення виробництва, що потребує використання обсягів використання води. Проте, частково витрати електроенергії зумовлені високим рівнем старіння основних засобів водопровідно-каналізаційного господарства. За даними обласних адміністрацій, найбільша питома вага (понад 50\%) аварійних та ветхих водопровідних мереж у Луганській та Донецькій областях. У 5 областях, серед яких Волинська, Львівська, Харківська та м. Київ цей показник коливався від 40 до 50 \%. Найнижчий відсоток (до $30 \%)$ у Вінницькій, Миколаївській, Сумській, та Закарпатській області.
Позитивним $€$ незначне зниження середнього відсотку старих та аварійних систем водопостачання у 2018 порівняно 3 попереднім періодом (-9,2 \%), що відбулося за рахунок замін або модернізації окремих систем. Серед лідерів щодо здійснення процесів модернізації в галузі протягом 2018 року $€$ Чернівецька область, де оновлено та модернізовано $17 \%$ водопроводів 3 тих, що потребували заміни.

Впровадження інноваційних технологій в системи водопостачання та водовідведення міських агломерацій потребує комплексного стратегічного планування розвитку територій та визначення відповідності поточного стану водопровідних та каналізаційних мереж стану, необхідному для забезпечення безперебійного постачання якісної води відповідно до реальних потреб населення. Важливими завданнями, що потребують вирішення також $є$ :

- заміна морально застарілого і технічно зношеного обладнання в системах на нові прилади з високим коефіцієнтом корисної дії, що дозволить оптимізувати тиск подачі води в будинки, підвищить енергоефективність водопостачання та знизить рівень аварійності мережі в цілому;

- підвищення якості питної води шляхом: модернізації очисних споруд та впровадження нових технологій очистки, підвищення санітарного контролю в зонах водозабору, заміни ветхих трубопроводів.

- розрахунок водного балансу для визначення реальних обсягів стічних води та відповідно необхідних потужностей насосного обладнання;

- модернізація систем аерації;

- впровадження нових технологій очищення піднятих та стічних вод.

Враховуючи сучасний стан інфраструктури водного господарства, одним з першочергових завдань у процесі формування міських агломерацій $\epsilon$ оцінка стану водо забезпечення територій, розроблення генеральних планів водопостачання і водовідведення у відповідності до потреб населення та наявних природних акваторій, формування ефективних механізмів впровадження інноваційних ресурсо- та енергозберігаючих технологій в галузі.

Проведене дослідження показало, що наразі існує багато інноваційних можливостей щодо оптимізації системи ЖКГ міських агломерацій, серед яких: поява та розвиток інформаційних технологій в управління містом та окремими сферами ЖКГ у тісній взаємодії зі споживачами послуг, розвиток інженерних технологій, нових матеріалів та обладнання для модернізації систем тепло-, енерго-, водопостачання, збору та утилізації відходів, застосування відновлювальних джерел 
www.econa.org.ua

енергії. 3'являються також нові джерела та інструменти залучення коштів в проекти, що мають важливе екологічне та соціальне значення. А саме: міжнародні гранти, «зелені облігації», краудфандинг та інші. Перехід українських міст та постелень до моделі сталого розвитку, в тому числі у сфері житлово-комунального господарства, потребує насамперед вдалого завершення процесів децентралізації, стабілізації адміністративного устрою та розподілу повноважень, визначення чітких механізмів функціонування бюджетів ОТГ.

\section{Висновки та перспективи подальших розвідок}

Досліджено особливості та основні напрямки впровадження інноваційних технологій у розрізі основних функціональних сфер житловокомунального господарства, а саме: технології модернізації житлового фонду у контексті забезпечення енергозбереження; напрями модернізації та підвищення енергоефективності систем теплопо- та енергопостачання, ресурсозберігаючі та екологічно безпечні системи водопостачання, водовідведення та очищення стічних вод; впровадження альтернативних джерел енергії для зміцнення енергетичної безпеки міських агломерацій; оптимізації систем транспортного забезпечення міст в напрямку розширення сфер використання міського транспорту та підвищення його екологічності, розвитку інформаційних технологій управління транспортними потоками, стимулювання переходу на екологічно безпечні види транспорту. Систематизовано проблеми та перспективні можливості впровадження інноваційних технологій в житлово-комунальній сфері із врахуванням зарубіжного досвіду.

\section{СПИСОК ВИКОРИСТАНИХ ДЖЕРЕЛ}

1. Ровенчак Т. Г., Шевчук С. В. Проблеми інноваційного розвитку житлово-комунального

господарства.

URL:

https://conferences.vntu.edu.ua/in dex.php/itb/itb2016/paper/viewFile /1592/1293

2. Україна комунальна. URL: http://jkg-

portal.com.ua/ua/publication/one/ nfografka-osnashhennja-Ichilnikamitepla-zhitlovih-budvel-tanezhitlovih-budvel-ukrajini-57023

3. Національна доповідь про якість питної води та стан питного водопостачання в Україні у 2018 році. URL: https://www.minregion.gov.ua/wpcontent/uploads/2019/11/ProektNats.-dop.-za-2018.pdf.

\section{REFERENCES}

1. Rovenchak, T. G. and Shevchuk, S. V. (2016). Problems of innovative development of housing and communal services. Retrieved from: https://conferences.vntu.edu.ua/in dex.php/itb/itb2016/paper/viewFile /1592/1293. [in Ukrainian].

2. Ukraine is communal. (2020). Retrieved from: http://jkg portal.com.ua/en/publication/one/ nfografka-osnashhennja-Ichilnikamitepla-zhitlovih-budvel-tanezhitlovih-budvel-ukrajini-57023. [in Ukrainian].
4. Міністерство розвитку громад i територій. URL: https://www.minregion.gov.ua/nap ryamki-

diyalnosti/zhkh/terretory/stansfery-povodzhennya-z-pobutovymyvi.

5. Irtyshcheva I., Kramarenko I., Shults S., Boiko Y., Blishchuk K., Hryshyna N., Popadynets N., Dubynska I., Ishchenko $O$. and Krapyvina D. Building favorable investment climate for economic development. Accounting. 2020. Volume 6 Number 5. Pp. 773-780.

6. Рогатіна Л. П., Іртищева І. О., Крамаренко І. С., Андрющенко Є.Г., Білан В. В. Інвестиційна складова економічної безпеки: мікро-, мезо-, макрорівні. Ефективна економіка. 2020. № 5. URL: http://www.economy.nayka.com.ua /?op=1\&z=7871.

3. National report on drinking water quality and drinking water supply in Ukraine in 2018. (2018). Retrieved from:

https://www.minregion.gov.ua/wpcontent/uploads/2019/11/ProektNats.-dop.-za-2018.pdf. [in Ukrainian].

4. Ministry of Community and Territorial Development. (2020). https://www.minregion.gov.ua/nap ryamki-

diyalnosti/zhkh/terretory/stansfery-povodzhennya-z-pobutovymyvi. [in Ukrainian]
7. Іртищева І. О., Стегней М. І., Паук М. І. Методичні підходи до визначення рівня інвестиційної привабливості галузі, підприємства. Вісник ХНАУ. Серія : Економічні науки. 2014. № 7. C. 316-328.

8. Крамаренко І. С., Іртищева І. О., Сєнкевич О. Ф., Топчій О. О., Войт Д. С. Структурно-динамічні характеристики інвестиційних ресурсів регіонів. Ефективна економіка. 2020. № 3. URL: http://www.economy.nayka.com.ua /pdf/3_2020/82.pdf.

5. Irtyshcheva, I., Kramarenko, I. Shults, S., Boiko, Y., Blishchuk, K., Hryshyna, N., Popadynets, N., Dubynska, I., Ishchenko, O. and Krapyvina, D. (2020). Building favorable investment climate for economic development. Accounting, 6 (5), 773-780.

6. Rogatina, L. P., Irtyshcheva, I. O. Kramarenko, I. S., Andryushchenko, E. G. and Bilan, V. V. (2020). Investment component of economic security: micro-, meso-, macrolevels. Efficient economy, 5, Retrieved from: http://www.economy.nayka.com.ua /?op=1\&z=7871. [in Ukrainian]. 
www.econa.org.ua

7. Irtyshcheva, I. O., Stegney, M. I. and Pauk, M. I. (2014). Methodical approaches to determining the level of investment attractiveness of the industry, enterprise. Bulletin of KhNAU. Series: Economic Sciences, 7, 316-328. [in Ukrainian].
8. Kramarenko, I. S., Irtyshcheva, I. O., Senkevich, O. F., Topchiy, O. O. and Voit, D. S. (2020). Structural and dynamic characteristics of investment resources of regions. Effective Economy, 3. Retrieved from:

http://www.economy.nayka.com.ua /pdf/3_2020/82.pdf. [in Ukrainian]. 